\title{
A STUDY ON PERCEPTION OF STOCK MARKET INVESTMENT WITH SPECIAL REFERENCE TO ANGEL BROKING LIMITED IN CHENNAI
}

\author{
Dr. S. Mayilvaganan
}

Assistant Professor of Commerce, and A.V.C. College (Autonomous), (Affiliated to Bharathidasan University), Mayiladuthurai, Tamilnadu, India

\begin{abstract}
N. Suganthi
Research Scholar A.V.C. College (Autonomous), (Affiliated to Bharathidasan University), Mayiladuthurai, Tamilnadu, India
\end{abstract}

\begin{abstract}
This paper identify the major factors that influences the investors' perception in stock market investment. Investors are the pillars of the stock market. This study focuses the investor's perception towards various aspects regarding to investment in share. This study attempts to answer various unanswered questions like; for what purpose they invest in equity share; which type of risk they are facing; what are the factors influencing to invest in share, etc.
\end{abstract}

Key words: Investors, Equity share, Perception

Cite this Article: S. Mayilvaganan and N. Suganthi, A Study on Perception of Stock Market Investment with Special Reference to Angel Broking Limited in Chennai, International Journal of Management, 11(12), 2020, pp 2669-2674.

http://iaeme.com/Home/issue/IJM?Volume=11\&Issue=12

\section{INTRODUCTION}

Now a day's investment habits are increased rapidly in our country. Investors are more aware about their investment. They would like to invest their money safely and earn high return. So they are going to invest their money in stock market. Stock market provides various investment avenues to their investors. Among these avenues, equity share occupies a significant role in the stock market.

\section{STATEMENT OF THE PROBLEM}

Investment in stock market provides lot of returns to the investors. One who has capacity to take risk has an eligibility to invest in stock market. This study made an attempt to know the 

in Chennai

investment pattern, level of risk and also to know the level of awareness of the investors because without awareness no one can enter the stock market. It also to identify the various problem faced by the investors.

\section{NEED FOR THE STUDY}

This study highlights the factors influencing the perception of investors in share. It is essential for a company to identify various factors on which basis a company can attract its investors. The study of this nature is useful for the academicians to know about the recent issues on investment in shares.

\section{OBJECTIVES OF THE STUDY}

- To study the preference of investors about the level of return on investment in equity.

- To analyse the income level of investors investing in share.

- To identify reasons for investment in share.

\section{LIMITATIONS OF THE STUDY}

- The present study restricted only to Equity Share only.

- Due to paucity of time, 50 respondents in Chennai city

\section{Hypothesis}

- There is no relationship between gender and Expected return on investment

- There is no relationship between age and Expected return on investment.

- There is no relationship between annual income and Expected return on investment.

- There is no relationship between annual income and average amount invested in equity.

- There is no relationship between occupation and average amount invested in equity,

- There is no association between educational qualification and amount invested in equity

\section{ANALYSIS AND DISCUSSION}

Table 1 Demographic Profile of the Investors

\begin{tabular}{|c|c|c|c|}
\hline \multicolumn{2}{|c|}{ Particulars } & No of respondents & Percentage (\%) \\
\hline \multirow{3}{*}{ Gender } & Male & 40 & 80 \\
\hline & Female & 10 & 20 \\
\hline & Total & 50 & 100 \\
\hline \multirow{5}{*}{ Age } & $20-30$ & 10 & 20 \\
\hline & $31-40$ & 24 & 48 \\
\hline & $41-50$ & 14 & 28 \\
\hline & $>50$ & 2 & 4 \\
\hline & Total & 50 & 100 \\
\hline \multirow{5}{*}{$\begin{array}{l}\text { Annual } \\
\text { Income }\end{array}$} & $<1,00,000$ & 2 & 4 \\
\hline & $\begin{array}{l}1,00,001- \\
3,00,000\end{array}$ & 4 & 8 \\
\hline & $\begin{array}{l}3,00,001- \\
5,00,000\end{array}$ & 4 & 8 \\
\hline & $\begin{array}{l}\text { Above } \\
5,00,001\end{array}$ & 40 & 80 \\
\hline & & 50 & 100 \\
\hline \multirow{4}{*}{$\begin{array}{l}\text { Educational } \\
\text { Qualification }\end{array}$} & Up to HSE & 2 & 4 \\
\hline & UG & 4 & 8 \\
\hline & PG & 26 & 52 \\
\hline & Others & 18 & 36 \\
\hline
\end{tabular}




\begin{tabular}{|l|l|c|c|}
\hline & Total & 50 & 100 \\
\hline \multirow{4}{*}{ Occupation } & Agriculturists & 2 & 4 \\
\cline { 2 - 4 } & Monthly salaried & 6 & 8 \\
\cline { 2 - 4 } & Business & 26 & 52 \\
\cline { 2 - 4 } & Professional & 18 & 36 \\
\cline { 2 - 4 } & Total & 50 & 100 \\
\hline
\end{tabular}

Source: primary data

Table 1 states the demographic background shows $80 \%$ of the investors are male and the remaining are female. Among the 50 respondents, $48 \%$ of the respondents are in the age group of $31-40$ and $28 \%$ of investors are in age group of $41-50$. Out of 50 sample $80 \%$ of investors earned 3,00,001 - 5,00,000 rupees. Likewise $72 \%$ of investors are qualified with PG. The majority of investors were doings business they occupied $52 \%$ total investors.

Table 2 Association between Gender and Expected Return on Investment

\begin{tabular}{|l|c|c|c|c|}
\hline \multirow{2}{*}{ Particulars } & \multicolumn{3}{|c|}{ Return on investment } & \multirow{2}{*}{ Total } \\
\cline { 2 - 4 } & High & Medium & Low & \\
\hline Male & 10 & 24 & 6 & 40 \\
\hline Female & 4 & 4 & 2 & 10 \\
\hline Total & 14 & 28 & 8 & 50 \\
\hline Chi-x2 value $=2$ \\
\hline d.f $=2$ \\
\hline Significance $=5 \%$ \\
\hline
\end{tabular}

Source: primary data

Table 2 shows the association between gender and expected return on investment towards the equity share. The above chi-square analysis reveals that the calculated value being 2 smaller than the table value $5.99 @ 5 \%$ level of significance with d.f $=2$. Therefore the null hypothesis was accepted. Hence there is no association between the gender and expected return on investment.

Table 3 Association between Age and Expected Return on Investment

\begin{tabular}{|c|c|c|c|c|}
\hline \multirow{2}{*}{ Particulars } & \multicolumn{3}{|c|}{ Return on investment } & \multirow{2}{*}{ Total } \\
\cline { 2 - 4 } & High & Medium & Low & \\
\hline $20-30$ & 4 & 6 & 0 & 10 \\
\hline $31-40$ & 6 & 14 & 4 & 24 \\
\hline $41-50$ & 2 & 8 & 4 & 14 \\
\hline$>50$ & 0 & 2 & 0 & 2 \\
\hline Total & 12 & 30 & 8 & 50 \\
\hline Chi-x2 value $=2.51$ & \\
\hline d.f $=6$ \\
\hline Significance $=5 \%$ \\
\hline
\end{tabular}

Table 3 shows the association between age and return on investment towards the equity share. The above chi-square analysis reveals that the calculated value be 2.51 is smaller than the table value $12.59 @ 5 \%$ level of significance with d.f $=6$. Therefore the null hypothesis is accepted. Hence there is no association between the age and return on investment. 
A Study on Perception of Stock Market Investment with Special Reference to Angel Broking Limited in Chennai

Table 4 Association between Annual Income and Expected Return on Investment

\begin{tabular}{|l|c|c|c|c|}
\hline \multirow{2}{*}{ Particulars } & \multicolumn{3}{|c|}{ Return on investment } & \multirow{2}{*}{ Total } \\
\cline { 2 - 4 } & High & Medium & Low & \\
\hline$<1,00,000$ & 0 & 2 & 0 & 2 \\
\hline $1,00,001-3,00,000$ & 0 & 2 & 2 & 4 \\
\hline $3,00,001-5,00,000$ & 0 & 4 & 0 & 4 \\
\hline Above5,00,001 & 12 & 22 & 6 & 40 \\
\hline & 12 & 30 & 8 & 50 \\
\hline Chi-x2 value $=4.35$ & \multicolumn{4}{|l}{} \\
\hline d.f $=6$ \\
\hline Significance $=5 \%$
\end{tabular}

Source: primary data

Table 4 shows the association between annual income and return on investment towards the equity share. The above chi-square analysis reveals that the calculated value 4.35 is smaller than the table value $12.59 @ 5 \%$ level of significance with d.f $=6$. Therefore the hypothesis is accepted. Hence there is a no association between the age and expected return on investment.

Table 5 Association between Annual Income and Amount Invested in Equity

\begin{tabular}{|l|c|c|c|c|c|}
\hline \multirow{2}{*}{ Particulars } & & \multicolumn{3}{c|}{ amount invested in equity } & \multirow{2}{*}{ Total } \\
\cline { 2 - 5 } & $<20$ & $21-30$ & $31-40$ & $>40$ & \\
\hline$<1,00,000$ & 2 & 0 & 0 & 0 & 2 \\
\hline $1,00,001-3,00,000$ & 0 & 2 & 0 & 2 & 4 \\
\hline $3,00,001-5,00,000$ & 0 & 2 & 2 & 0 & 4 \\
\hline Above5,00,001 & 0 & 0 & 0 & 40 & 40 \\
\hline & 2 & 4 & 2 & 42 & 50 \\
\hline & Chi- 22 value $=56.09$ \\
\hline & d.f $=9$ \\
\hline
\end{tabular}

Source: primary data

Table 5 shows the association between annual income and return on investment towards the equity share. The above chi-square analysis reveals that the calculated value 56.09 is smaller than the table value 16.91@ $5 \%$ level of significance with d.f $=9$. Therefore the null hypothesis is rejected. Hence there is an association between the annual income and amount invested in equity.

Table 6 Association between Educational Qualification and Amount Invested in Equity

\begin{tabular}{|l|c|c|c|c|c|}
\hline \multirow{2}{*}{ Particulars } & & \multicolumn{3}{c|}{ amount invested in equity } & \multirow{2}{*}{ Total } \\
\cline { 2 - 5 } & $<20$ & $21-30$ & $31-40$ & $>40$ & \\
\hline Up to HSE & 0 & 0 & 0 & 2 & 2 \\
\hline UG & 0 & 0 & 0 & 4 & 4 \\
\hline PG & 0 & 2 & 0 & 24 & 26 \\
\hline Others & 2 & 2 & 2 & 12 & 18 \\
\hline Total & 2 & 4 & 2 & 42 & 50 \\
\hline & Chi $-\mathrm{x} 2$ value $=8.61$ \\
\hline & d.f $=9$ \\
\hline
\end{tabular}

Source: primary data 
Table 6 shows the association between annual income and return on investment towards the equity share. The above chi-square analysis reveals that the calculated value 8.61 is smaller than the table value 16.91@ $9 \%$ level of significance with d.f $=9$. Therefore the null hypothesis is accepted. Hence there is no association between the educational qualifications and return on investment.

Table 7 Association between Occupation and Amount Invested in Equity

\begin{tabular}{|l|c|c|c|c|c|}
\hline \multirow{2}{*}{\multicolumn{1}{|c|}{ Particulars }} & \multicolumn{3}{|c|}{ amount invested in equity } & \multirow{2}{*}{ Total } \\
\cline { 2 - 5 } & $<20$ & $21-30$ & $31-40$ & $>40$ & \\
\hline Agriculturists & 0 & 0 & 0 & 2 & 2 \\
\hline Monthly salaried & 2 & 0 & 0 & 6 & 8 \\
\hline Business & 0 & 4 & 2 & 30 & 36 \\
\hline Professional & 0 & 0 & 0 & 4 & 4 \\
\hline Total & 2 & 4 & 2 & 42 & 50 \\
\hline & Chi-x2 value $=4.39$ \\
\hline & d.f $=9$ \\
\hline & \multicolumn{4}{l}{} \\
\hline
\end{tabular}

Source: Primary data

Table 7 shows the association between occupation and return on investment towards the equity share. The above chi-square analysis reveals that the calculated value 8.61 is smaller than the table value 16.91@5\% level of significance with d.f =9. Therefore the null hypothesis is accepted. Hence there is no association between the occupation and return on investment.

\section{FINDINGS}

The major findings of the study are as follows

- The maximum number (48\%) of investors who are investing in shares coming under the age group of $31-40$.

- It was found that $72 \%$ of investor's educational qualification was PG. It was inferred that $52 \%$ of respondents were doing business.

- It was found that the investors who are investing in share only for high return.

- It was inferred that majority of investors invest more than Rs. 40,000 in share and they expects medium return.

- It was found that all the investors were doing online trading and the majority of investors investing in Retail Company.

- It was found that there was no association between Age, Gender, and Expected Return on Investment.

- It was found that there was no association between Annual Income and Return on Investment.

- It was found that there was an association between Annual Income and Average Amount Invested in share.

\section{SUGGESTIONS}

From the above survey, many of the female investors have the fear of loss of investment they need knowledge and awareness about their investment in stock market. So each and every broking firms has conduct awareness programs frequently. Advertisement plays an important role in creating awareness on investment in share market so more weightage may be given for advertisement for increase the investment decisions of investors in share market. 


\section{CONCLUSION}

The present study helps to analyses the perception of investors towards share. The investment habit of the investors is increased rapidly. In our country there are lot of investment avenues are available such as Real estate, Equity, Bond, Life Insurance, Bank Savings, etc,. The investors are more aware about their investment they analyses the various investment avenues which one is more suitable, safe and profitable. This ensures them to choose less risky and more profitable instruments. The investor should track the market environment with sound knowledge about an equity would result in better return.

\section{REFERENCES}

[1] Bekaert, G, CR. Hervy and R.L.Lumsdaine (2002), 'the dynamics of Emerging Market Equity Flow', Journal of International money and finance, 21(3): 295-350.

[2] Hsin,c.(2004)., 'A Multilateral Approach to Examining the Comovements amoung Major World Equity Markets', International Review of financial studies,3(2):281-307.

[3] Sunil S.Poshakwale, Chandra Thapa (2010), 'Foreign Investors and Global Integration of Emerging Indian Equity Market', Journal of Emerging Market Finance9:1 1-24.

[4] M.Lokanatha reddy (2014), 'Investors Perception towards Investment in Mutual Funds- A Study with Reference to Bangalore North’, Indian Journal of Finance,9:2 13-19.

[5] Capital Market - Dr.S.Gurusamy (Tata McGraw-Hill Education Pvt Ltd)

[6] Security Analysis and - Shashi K.Gupta \& Rosy joshi (Kalyani Publishing Portfolio Management House)

[7] Investment Management - M Sulochana (Kalyani Publishing House) 